\title{
Dentist apprentice
}

We are nowadays so clued into the idea of GCE A-levels, five years at dental school, a year (or possibly two) of vocational training and then a career life-long learning process that the notion of anything less seems fanciful. And as for apprenticeships, well dental education has come on in leaps and bounds since those days. Hasn't it? Stephen Hancocks takes another look.

D ifficult to imagine, then, what it must have been like to be an apprentice - a dentist's apprentice, to be precise. But that, of course, is how it was done. No curriculum document then, no First Five Years, just the good old fashioned notion that experience was everything and that there was nothing in the way of tooth-drawing or the placing of 'ye olde stoppings' in teeth that could not be picked up at the feet of a master or mistress. No, pretty much just a master I'm sorry to report. At the risk of bringing down the wrath of a sizeable proportion of today's profession, in those days of yore it has to be conceded that women in dentistry would have been closer, one suspects, to wenches in dentistry.

Gender aside, it must have been a strange process: taking on a likely lad to study the skills and artistry of dentistry straight away on live specimens. It is interesting to speculate as to at which point in an apprentice's training he first tackled a real patient. Perhaps that aspect isn't so different from today's patients in that presumably the hapless Victorian didn't actually know that they were being a 'first', performing the role of a premier patient?

To begin with, the young whipper-snapper had no $B D J$ classified jobs section to check what was available (how did they manage?) and so would probably have had some family connections or at least been the son of a friend. Having parents teach one to drive a car is bad enough, let alone design class II cavities with buccal extensions. Except that was not exactly an option back then. Rather like the apprentice organist, the first task was to pump up enough air to make the notes possible and to raise enough pedal power in the surgery to allow the medieval high speed bur to revolve sufficiently quickly so as not to stop the instant it touched tooth tissue. 'Wanted: Eager young chap with interest in human biology and good leg muscles' would presumably have been a prime part of any advert nailed on a Wimpole Street lamppost.

Then there was the tricky business of being able to see what was going on. Fine nowadays with intra-oral cameras, video links and distant monitors; but with barely a focused candle flame to guide the novice, the task of seeing exactly where to place the fulcrum of the key to raise the buried wisdom tooth must have required excellent eye sight. And not a little flexibility in the neck department, either!

\section{"Having parents teach one to drive a car is bad enough, let alone design class II cavities with buccal extensions."}

At least dental materials would have been simpler. No awkward questions about the potential danger of mercury, nor whether or not to fit a rubber dam every time a composite was to be placed. Imagine; fluoride had not even been discovered and fissures happened only in ice packs in lantern slide presentations of Antarctic expeditions. Indeed, the main consideration was presumably the size of mallet that it was possible to bang up and down inside the mouth to burnish a cohesive gold inlay. That must have sorted out the sheep from the goats.

As for the business side of things, what a wonderful cinch compared with today's practice management hurly-burly and needsbe, customer centred approach. It was largely a matter of attracting wealthy patrons and then retaining them. The practice informa- tion brochure would have consisted of an advert in the local newspaper surrounded by an intricately scrolled border announcing the times at which Mr Barber-Surgeon would be in attendance and the painless method of his technique. No need either for twenty-first century requirements like wheelchair access and baby changing areas, although horse and carriage parking facilities (optional grooming and ostler valet service also available at an additional modest fee) might have provided that slight edge in a citycentre location.

However, all the apprentice needed to pick up was a foolproof method of remembering which daughter was to marry the local clergyman and which son was off to captain a regiment in the Punjab, so as to be able to indulge in meaningful small talk while the local worthy's ivory dentures were being carved to fit. As for the dental team, well that too was also still in its infancy. No high-volume suction equipment to require the services of a sharp-eyed, steady-handed dental nurse; the scullery maid made a passable substitute for a receptionist. But the idea of practice managers or hygienists, the anxieties of staff meetings, democracy in the work place, no smoking policies and Investors in People were not high on the apprentice's agenda of home study when the mantlepiece clock in the waiting parlour chimed to mark the day's conclusion of business.

We can reassure ourselves that the image of the student as apprentice is way past. No longer the hovering about in the surgery of an older, experienced colleague. Except of course in the modern concept of 'mentoring'. But that is different because of technology for a start and the commercial aspects, marketing for example, and the plethora of materials about which to be knowledgeable. Learning on the job, perish the thought. Pass me another VDP. $/$ 